Western University

Scholarship@Western

Aboriginal Policy Research Consortium International (APRCi)

2008

\title{
The Maori of Tourist Brochures Representing Indigenousness
}

Kjell Olsen

Follow this and additional works at: https://ir.lib.uwo.ca/aprci

Part of the Tourism Commons

Citation of this paper:

Olsen, Kjell, "The Maori of Tourist Brochures Representing Indigenousness" (2008). Aboriginal Policy Research Consortium International (APRCi). 180.

https://ir.lib.uwo.ca/aprci/180 
This article was downloaded by: [University of Western Ontario]

On: 18 November 2012, At: 06: 24

Publisher: Routledge

Informa Ltd Registered in England and Wales Registered Number: 1072954

Registered office: Mortimer House, 37-41 Mortimer Street, London W1T 3J H, UK

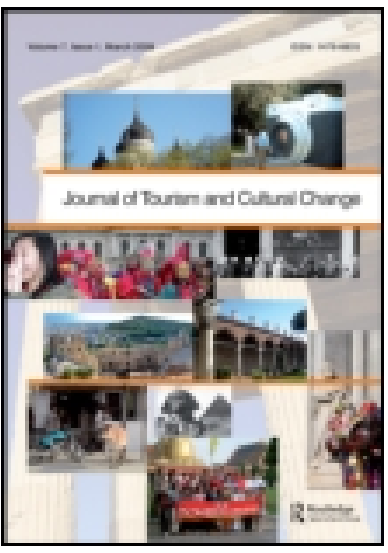

\title{
J ournal of Tourism and Cultural Change
}

Publication details, including instructions for authors and subscription information:

http:// www.tandfonline.com/loi/ rtcc20

\section{The Maori of Tourist Brochures Representing Indigenousness}

\author{
Kjell Olsen ${ }^{a}$ \\ a Department of Tourism and Media, Finnmark University \\ College, Follumsvei, Norway \\ Version of record first published: 22 J an 2009.
}

To cite this article: Kj ell Olsen (2008): The Maori of Tourist Brochures Representing Indigenousness, J ournal of Tourism and Cultural Change, 6:3, 161-184

To link to this article: http:// dx.doi.org/ 10.1080/ 14766820802553152

\section{PLEASE SCROLL DOWN FOR ARTICLE}

Full terms and conditions of use: http://www.tandfonline.com/page/terms-andconditions

This article may be used for research, teaching, and private study purposes. Any substantial or systematic reproduction, redistribution, reselling, loan, sub-licensing, systematic supply, or distribution in any form to anyone is expressly forbidden.

The publisher does not give any warranty express or implied or make any representation that the contents will be complete or accurate or up to date. The accuracy of any instructions, formulae, and drug doses should be independently verified with primary sources. The publisher shall not be liable for any loss, actions, claims, proceedings, demand, or costs or damages whatsoever or howsoever caused arising directly or indirectly in connection with or arising out of the use of this material. 


\title{
The Maori of Tourist Brochures Representing Indigenousness
}

\author{
Kjell Olsen \\ Department of Tourism and Media, Finnmark University College, \\ Follumsvei, Norway
}

This study analyses how Maori operators in the tourist industry portray indigenous culture in their brochures. For close to 150 years, Maori people have been involved as entrepreneurs in New Zealand's tourist industry. Although now integrated into the modern New Zealand nation-state, the representation of their culture in tourism gives an image of a traditional people radically different and set apart from modern New Zealand (Kiwi) culture. Utilising Fabian's ideas regarding the organisation of otherness through cultural constructions of time and space, this article demonstrates how certain spatial arrangements are necessary to sustain the imaginary temporary division between a modern Kiwi culture and the representation of a traditional Maori culture, the latter is a tourist attraction in itself. Auto-ethnography in the discourse of tourism inevitably becomes 'self-Orientalism', even if some spaces makes co-presence possible.

doi: $10.1080 / 14766820802553152$

Keywords: indigenous peoples, Maori, tourist brochures, auto-ethnography

Tourism is not a product since it cannot be sampled in advance. It is a collection of projected images which establishes the boundaries of experience. The images define what is beautiful, what should be experienced and with whom one should interact. Understanding the people of tourism is thus, above all else, an analysis of images. (Dann, 1996: 79) ... by packaging and quantifying Maori cultural items within Pakeha definitions the control over what these items might mean shifts from Maori to Pakeha, and by redefining these cultural items into self-contained components they become susceptible to market forces, in that their "value" is more dependent upon economic considerations than cultural considerations. (Smith, 1993: 9 quoted from Bishop \& Glynn, 1999: 26)

Indigenous peoples increasingly claim the right to represent their own culture and history. These processes are in many ways captured by Pratt's (1992: 7) notion of 'auto-ethnography'. According to her, the concept refers to: '... instances in which the colonized subjects undertake to represent themselves in ways that engage with the colonizers' own terms [...] ... in response to or in dialogue with those metropolitan representations' (Pratt, 1992: 7; italics in original). Typically, scholars have paid more attention to such auto-ethnography when it can be captured by the colonisers' own terms of art, social science, history or political articulation than when such self-representations are 
subsumed under the heading of popular culture, even if the latter might reach a larger audience. Consequently, it is quite possible that many Maori tourist brochures have a much wider readership than Hulme's (1984/2001) Booker-prize novel, The Bone People. For that reason, such publicity can be well worth analysing. As Said (1978: 2-3) claimed for 'Orientalism', this discourse on the Other is an intertwining of institutions that contains both scholarly pursuits of knowledge and an anecdotal understanding of the quotidian. Tourism is definitely among those activities that add to such anecdotal understanding.

Dann's (1996) study of how the relationship between tourists and locals is portrayed in tourist brochures targeted at the British market is a starting point for this analysis. Dann demonstrates that in only $10 \%$ of the pictures do locals and tourists appear together and that the tourists dominate most of the locations. My research question is: How does the indigenous Maori as a tourist product fit into this general picture? I utilise Dann's methodological framework to make a controlled comparison (Bruner, 2001; Eggan, 1954) between brochures promoting tourism in general, brochures on two particular destinations, and brochures in which an indigenous population is the object of the tourist gaze. Following Dann's approach to the study of tourist brochures, the present article examines how tourist companies in the two areas of Rotorua and Lake Taupo, in New Zealand, represent Maori culture as tourist attractions in their brochures. Such representation is mainly self-representation - or auto-ethnography - in which predominantly Maori-owned companies and communities with a substantial Maori population engage with the global discourse of tourism.

The discourse of tourism is an integral part of modernity and can be regarded as founded on a number of fundamental binaries of Western thinking. The culturally recognised oppositions between technology and nature, work and leisure, and the assumed difference between an alienating modernity and certain zones where authenticity in various forms can be experienced are all seen as necessary underpinnings for the phenomenon known as modern tourism (MacCannell, 1976/1999; Urry, 1990; Wang, 2000). What the analysis of Maori tourist brochures reveals is that this auto-ethnography is carried out mainly within the framework of the Western-colonial distinction between the traditional and the modern. The image of the Maori as a tourist attraction appears only in certain zones, while being denied access at other locations where tourism is performed. In this way, the idea of separation between the traditional indigenous visited and the modern visitor is upheld by classificatory spaces that reduce the significance of time as an ordering element in this relationship (Fabian, 1991: 198).

From the foregoing observations, it should be clear that the way the Maori are represented in tourist brochures also indicates in what realms of society the distinction between the traditional and the modern can be expressed. More importantly, it highlights in what domains this Western-colonial discourse refuses access to such differences, promoting instead an assumed unbiased modernity. Nevertheless, in spite of a general tendency to separate tourists from the Maori as traditional attractions, these brochures also indicate that, in certain spaces, the indigenous can be portrayed as contemporary and co-present with the visitors. 


\section{Theoretical Background}

In short, one of Fabian's (1991) main arguments in his book Time and the Other is that, although ethnographic fieldwork occurs in a context of co-presence and inter-subjective communication, 'the Other' appears as spatially and temporally distanced groups in ethnographic representation. In particular, this is the case for 'less developed' peoples that become fixed in a timeless present as opposite to modernity. This image of indigenous peoples also fits into modern tourism because, '[t]he more modern the locals become the less interest they have for the occidental tourist. Tourists come from the outside to see the exotic; from the inside, tourism is viewed as modernization' (Bruner, 1995: 224). Tourism understood as a quest for otherness, for the exotic, for the authentic, and for differences makes indigenous, ethnic, tribal, or traditional peoples attractive to tourists. As Wang (2000: 139) put it: 'Exoticism is thus an idealization of "Others" and "savages" in terms of the loss of authenticity, simplicity, and innocence in the home society'. And he goes on to say, '[t]he sensation of the exotic is, however, more often derived from exotic customs, cultures, and peoples, particularly when they are remote in both time and space' (Wang, 2000: 145).

'The Other' becomes an attraction by a Western-colonial binary turn of thought that situates them at a different stage of development, in a premodern time where the authentic supposedly are found. But as Friedman (1999: 315) pointed out:

... the indigenous is now a part of a larger inversion of Western cosmology in which the traditional other, a modern category, is no longer the starting point of a long and positive evolution of civilization, but a voice of Wisdom, a way of life in tune with nature, a culture in harmony, a [G]emeinschaft, that we all have but lost.

Hence, the - also for tourists - obvious co-presence of many indigenous peoples in modern societies makes it difficult to uphold this inversion of Western cosmology. As Fabian (1991: 198) claimed for ethnography, the idea of temporal division might be replaced by the construction of culturally constructed spaces where the Western-colonial image of the Other can still be seen. And as Dann (1996: 76) maintained, images are established in advance and they '... establish[...] the boundaries of experience. The images define what is beautiful, what should be experienced and with whom one should interact'. Adding an attention to social interaction, it might also be said that such images establish where to experience, and in this case in what culturally constructed spaces the Maori can be seen as, 'the Other' in Western cosmology.

This is not to say that tourists do not understand that the Maori are modern citizens living in a modern state. The concept 'organic images' is meant to cover the totality of what people know in advance or perceives about a place or possible destination for a holiday (Dann, 1999; Gunn, 1997). To understand the images of tourism, it is necessary to consider image building as a process that can be divided into several stages, such as pre-trip, on-trip, and post-trip (Dann, 1996, 2001: 5; Gunn, 1997: 29; Wang, 2000: 135-136). Therefore, the brochures that are analysed represent only a certain stage in this image-building 
process. They do not represent what the tourist actually imagines as Maori culture. Rather, the analysis reveals what actors in the tourist industry in the Lake Taupo area and in Rotorua aim to bring tourists to recognise as Maori attractions, when they can be seen as a Western inversion, and where to find them. In the process, the analysis also indicates what the industry does not regard as Maori attractions.

Limited research on the touristic portrayal of people labelled as ethnic or indigenous reveals that such representations are usually stereotypical in nature. In the case of people regarded as traditional, the representations in brochures are said usually to avoid the threatening image of adult males. Children, women, and elderly people are preferred in settings that do not relate to modernity (Dann, 1999, 2001; Wang, 2000). Often the images are 'eroticised' and 'exoticised' depictions of locals representing their traditional culture in entertaining performances for a predominantly Caucasian audience of tourists (Buzinde et al., 2006; Dann, 1996; Echtner, 2000). Concluding their findings in a Canadian context, Buzinde et al. (2006: 723-724) suggest '. . . that tourism provides its audience with images that rationalize the hosts' socio-cultural behavior and relegate them to times past, inherently robbing them of their identity, rather than allowing them to produce multiple contemporary identifications'. Hence the doubt might be raised as to whether tourists believe the images they are presented with and do not understand that people - indigenous or not - have multiple contemporary identities. Stereotyped images of indigenous people can be an attraction even if tourists know that they are produced for tourists. At the same time, the stereotyped images in tourism advertising do not necessarily mean that indigenous populations are incapable of utilising the touristic imagery for their own ends (Gingging, 2007).

To lump different together peoples into the categories of 'ethnic' or 'indigenous', as is often done in tourism research, can cause the huge variations in the way they are represented to be neglected, as well as hide significant differences in political and socio-economic status within different nation-states. An analysis of the representation of the Maori in tourist brochures must be set in a specific historical and political context. In Pratt's terminology, auto-ethnography exists in contact zones where indigenous peoples are actors. By using the concept of contact zone, Pratt (1992: 7) aims to emphasise '... copresence, interaction, interlocking understandings and practices, often within radically asymmetrical relations of power'. Therefore, analysis of the image of indigenous peoples in general often overlooks differences as well as the individuals' agency. As Hannerz (1996: 52) points out in general for what he labels a 'global ecumene', agents in social life are distributed differentially in relation to meta-cultures of difference and similarities, and these variations also have an impact on tourism representations.

\section{The Maori and Tourism}

In the 2006 national census, approximately one in seven people were identified with the Maori ethnic group (http://www.stats.govt.nz/census/). Although probably more, out of New Zealand's total population of about four million, can claim such an ethnicity, it should be noted that being a 
Maori can still be regarded as a disadvantage. Compared with many other peoples who have been lumped into the broad category of indigenous, the Maori have been fairly well integrated into a modern New Zealand state for a long time. Since the mid-1980s, Maori tribes have gained a relatively large degree of political recognition and influence in comparison with many other indigenous populations, as well as having regained particular rights to some natural resources (van Meijl, 2003). This is not to say that Maori people compete on equal terms with the dominant white population of New Zealand (Bishop \& Glynn, 1999; Webster, 1998). Rather, the Maori population is integrated in a modern nation-state in quite a different way from many other peoples covered by the broad term indigenous. Therefore, tourism research needs to pay attention to the differences found inside the frames of the broad category of indigenous peoples as well as emphasising structural features and power relations that still make 'indigenous' a meaningful concept (Lee, 2006).

Such differences and similarities are created, among others, by Westerncolonial narratives of the Other. As Sturma (1999: 713) puts it: 'From the beginning, Western contact with Polynesia was cast in terms of encountering not only a distant land, but a distant time. Pacific peoples were frequently represented as akin to ancient Greeks and Romans'. This view formed part of a debate on the classification of the Other in relation to different categories; were the Other human or non-human, or did they just lag behind in a temporal evolution? In the late 18th century there was: '.. . a fundamental change in Western thinking about the human inhabitants of the South Seas, a shift from a gaze dominated by the monstrous and the fantastic to another more deliberately rational and scientific' (Ryan, 2002: 158). The ordering of what became established as distinct races according to different geographical places continued during the Enlightenment, when peoples in the South Pacific were also attributed certain qualities (Ryan, 2002: 166ff.). This notion of the timelessness of Pacific peoples has been perpetuated by popular Western-colonial culture, along with the tourist industry, well into the 20th century (Sturma, 1999).

As Bruner (2001: 887-888) claims for the ethnographic Other in general, the representation of indigenous peoples is also linked to the ethnographic focus that has been placed on certain features. In the case of the Maori, this emphasis implies an ethnographic interest for and admiration of Maori warriors that can be dated back to the Enlightenment (Ryan, 2002) and which continued through the 19th century (King, 2003). This image of fierce warriors and certain selected features of Maori culture have also shown a high degree of persistency even if they have been influenced by the involvement in tourism (McIntosh et al., 2004; Neich, 1983; Ryan, 1997; Ryan \& Crotts, 1997). Ryan (1997: 260) points out the haka (the war dance), the poi (women's dance with feathers), and the wero (the ritual challenge with grimacing face, tongue poking out and rolling eyes) as themes that have remained constant on postcard pictures for the last 40 years. In addition, there are facial tattoos and the Maori tree-carving tradition, which became famous after being exhibited on tour in the United States in the 1980s (McCarthy, 2007: 135ff.; van Meijl, 2003: 54)

The representation of the Maori in tourism is also set in a contemporary political context. As far back as the last part of the 19th century, the Rotorua area, with its lakes, thermal activity, and White and Pink Terraces, called 'the eighth 
wonder of the world', had become an international tourist attraction. ${ }^{1}$ At this time, the local Maori community benefited substantially from tourism, and Maori people owned hotels and were in charge of guiding operations in the district. In this respect, the tourism industry did not differ from Maori entrepreneurship in other trades (King, 2003: 127, 187). Their financial involvement in the tourist industry disappeared early in the 20th century, and Maoris were turned into an attraction for the tourists' gaze. The Maori remained peripheral as actors in the New Zealand tourist industry until the 1980s (Barnett, 1997: 471-472).

What has been labelled the culmination of 'the Maori Renaissance' in the 1980s changed this situation (Webster, 1998). Today many Maori run businesses and in many respects are in charge of deciding how Maori culture should be presented. Maori control, questions of authenticity or sincerity, and therefore how Maori culture should be represented in a Maori way are topics that permeate this discourse (Asplet \& Cooper, 2000; Barnett, 1997; Ryan, 1997; Taylor, 2001; Young, 1989). The New Zealand political discourse on the relationship between Maori and Pakeha (Europeans) creates a political climate in which Maori culture can seldom be used as an attraction without the affirmation of some Maori, even if not necessarily all. This climate of political respect (as opposed to the dubious expression 'political correctness') can be illustrated by the controversy stirred up by the new national museum of New Zealand, Te Papa Tongarewa. The criticism was aimed at the contrasting ways in which Maori and Pakeha cultural items were displayed - the former in a reverential manner and the latter in a kind of "amusement arcade" of supposedly incoherent, temporary and mocking exhibits' (Goldsmith, 2003: 1).

The use of Maori culture has been and still is important in the international branding of New Zealand, even if the slogan 'Pure New Zealand' includes other elements as well. In recent years, the Maori have faced fierce competition from new tribes of Dwarfs, Elves, and Hobbits, vying for the ability to attract visitors to New Zealand (http://www.newzealand.com/travel).

\section{Method}

Compared with the visual aspect of tourism, less attention has been paid to the 'literary forms' of tourism (Dann, 1999, 2001; Robinson, 2005). Even if written texts are obviously an important part of tourism, they play only a minor role in the brochures under consideration here.

The brochures shown here promote two distinct regions, Rotorua and Lake Taupo, together with a number of attractions in these areas. The written texts concentrate mainly on what, where, and how to get there, and when and for what price. In sum, they constitute a language meant to enable visitors to perform acts of tourism once they have decided to visit the destination. The communication of the Maori as a product is predominantly visual, even if some of the texts reinforce the regression in time that is commonly attached to indigenous peoples (Picture 1).

Nevertheless, the brochures predominantly communicate their core product in this case the Maori - by the use of pictures, images that are examined in this article. The idea and framework of the analysis are derived from Dann's (1996) 


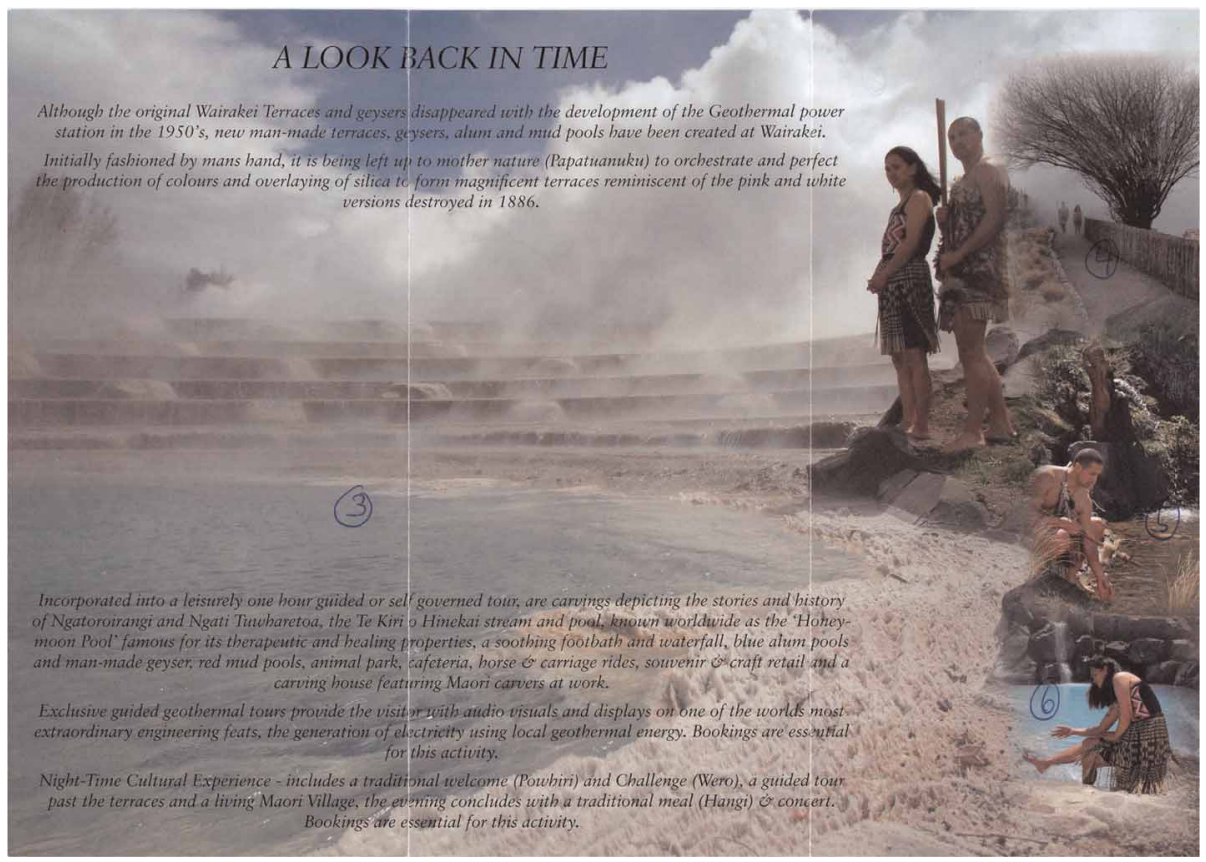

Picture 1. Wairakei Terraces, Taupo.

article The People of Tourist Brochures, first presented as a speech at the conference 'Tourism: a Vital Force for Peace', in Vancouver, Canada, in 1988. His study analyses how the relationship between visitors and locals is portrayed in 11 brochures targeted at a cross section of the British public (Dann, 1996: 63). Analysing 5172 pictures, Dann (1996: 64) concludes that '... for the mediamakers at least, the idea of tourism as a meeting of peoples was somehow not to be encouraged'. Since in less than $10 \%$ of all pictures tourists appeared together with local people, he continues:

In the remaining few cases the less attainable host society was portrayed as comprising persons in national costume forming part of the scenery, stereotypical cultural markers, middlemen, smilers or else as tourists themselves. At the same time, by means of well-known advertising devices, the operator attempted to persuade potential tourists to leave their unsatisfying homes and routines and travel to exotic destinations. In spite of the occasional unobtrusive presence of locals, there they would be able to discover themselves and their fellow sojourners. If tourists still wished to pursue the indigenous, that was their business; the remaining 90 percent of the trade still belonged to the operator. (Dann, 1996: 78-79)

Dann (1996: 63) reaches his conclusion in part through a quantitative content analysis, in which: 'Destination pictures were simply classified according to presence or absence of people and were subdivided into three categories: tourists only (one, two, three or more), local residents only (one, two, three 
or more) and tourists and locals together'. In the next stage of his analysis: 'The data were subsequently cross-tabulated by a number of settings: beaches, transport, hotels and their surroundings, tourist sights, local scenes, entertainment, sport (excluding swimming), and animals. In this way it was possible to see how hosts and guests were distributed across a range of tourist locations' (Dann, 1996: 64).

The research framework applied by Dann has been adapted to the present research on Maori brochures. The materials for the research were collected at Taupo Visitor Centre on the 13 and 20 of December 2003. The idea was first to use only brochures promoting products based on Maori culture in the Lake Taupo area. This was because Lake Taupo is among the main tourist destinations in the country and because of a belief shaped by previous visits that Taupo was a 'Maori area'.

In the event, only two of the more than fifty brochures found in the Taupo Visitor Centre that promoted activities in this area clearly fulfilled the predefined selection criteria of having a front page that related to what could be regarded as features of the Maori culture. Two more brochures were added because of the Maori relation in (1) the name: Orakei Korake Cave and Thermal Park (T1) and (2) the arty representation of indigenousness in Art and Craft Tour of Taupo (T4). T1 and T4 made up 36 of the 51 pictures found in Maori product brochures in Taupo.

The Visitor Centre also had a number of brochures that promoted the neighbouring town Rotorua. Rotorua has a much more prominent image as a 'Maori town' and a long tradition of Maori involvement in tourism. Five brochures from this smaller sample of approximately 20 were selected. Only one of these, Rotorua Museum/The Whare Taonga Te Arawe (R2) did not show Maori images on its front page. This brochure was selected because of the name and because of knowledge from a previous visit to the museum. Of the 91 pictures found in the Rotorua brochures, 20 were in R2.

Even if 143 pictures were discovered in these nine brochures, their dimensions ranged only from $1 / 2$ to full A4 size. The very large number of pictures was partly a result of collages that were divided and counted as separate pictures when they were clearly separable. It is also important to note that some pictures were 'repeated' in several brochures, probably because they were bought from the same companies (Table 1).

Repetition was also evident in the other part of the material that was made up of visitor guides for Lake Taupo and Rotorua. These two brochures, which covered two nearby destinations and therefore some of the same attractions, had, respectively, 254 (Lake Taupo Visitor Guide=LTVG) and 215 (Rotorua Visitor Guide=RVG) pictures. In the visitor guides, collage pictures were counted as one except when Maori motifs were considered.

\section{Analysis}

The two destinations aimed to promote different images even if sport, nature, and thermal phenomena were important for both. This difference was reflected in the visitor guides. Lake Taupo focused on outdoor activity, sport, and 'lifestyle'. The Rotorua Visitor Guide used 'spirit' as a catchword. Rejuvenate your 
Table 1 Brochures used in the research

\begin{tabular}{|c|c|}
\hline Brochures & Pictures \\
\hline \multicolumn{2}{|l|}{ Product brochures } \\
\hline \multicolumn{2}{|l|}{ Taupo } \\
\hline T1 The Hidden Valley & 14 \\
\hline T2 Wairakei Terraces & 12 \\
\hline T3 Kayak to the Carvings & 4 \\
\hline T4 Art and Craft Tour of Taupo & 22 \\
\hline Subtotal & 52 \\
\hline \multicolumn{2}{|l|}{ Rotorua } \\
\hline R1 Carey's Rotorua Tours & 20 \\
\hline R2 Rotorua Museum/Te Whare Taonga Te Arawa & 31 \\
\hline R3 Tamaki Maori Village & 9 \\
\hline R4 The New Zealand Maori Arts \& Crafts Institute & 21 \\
\hline R5 Buried Village of Te Wairoa & 10 \\
\hline Subtotal & 91 \\
\hline Total & 143 \\
\hline \multicolumn{2}{|l|}{ Visitor Guides } \\
\hline Lake Taupo & 254 \\
\hline \multirow[t]{2}{*}{ Rotorua } & 215 \\
\hline & 469 \\
\hline Total & 612 \\
\hline
\end{tabular}

Spirit, Spirit of Living Culture, Spirit of the Earth, Challenge your Spirit, Free your Spirit, Spirit of Rotorua, and Spirit of Innovation were used as headings to present the area (RVG, pp. 4-17). Rotorua tried to promote an image in which Maori culture played a prominent part, together with thermal activity and the long tradition of spas. It is interesting to note that, in the Rotorua brochures, 6 pages out of 56 fell under the label 'heritage and culture', whereas the Lake Taupo brochure with 51 pages devoted only 3 to heritage.

In the analysis, Maori motifs in the Maori product brochures were counted first. The obvious problem with both the collection of these brochures and the counting of Maori motifs was that already established categories were reified. The collection of brochures and the counting of motifs focus on emblematic - and usually traditional - symbols of Maori culture. Even so, the representation of indigenousness has become stereotyped in tourism (Wood, 1998), and in Western discourse in general (Said, 1978; Smith, 1999). Certain emblematic signs related to assumed earlier stages of development (e.g. the relation to nature and technology had become a standard way of exhibiting indigenous peoples). Therefore, a car - even if owned by a Maori - becomes a symbol of a modern Kiwi culture, and what is left to the Maori are mainly their traditions. Still, this division between the traditional and the modern has some validity because the Maori brochures themselves, in contrast to the 
brochures that promote the areas in general, are dominated by traditional motifs and demonstrate sometimes striking lack of motifs that relate to a Western modernity.

In addition, the Maori have their own history as exhibits in tourism and museums and the kind of cultural features that have been highlighted (McCarthy, 2007; Neich, 1983; Ryan, 1997; Ryan \& Crotts, 1997). In many of the pictures, these common Maori motifs were placed in settings that related to indigenousness in general. As Ryan (1997: 261) puts it: 'what is denied is the concept of Maori in the twentieth, much less the twenty-first century, as peoples of the contemporary area. There are no images of Maori sitting at their word processors!' Such usage was mainly correct for this material, except for few occasions where colour - or rather more accurately the idea of race - became the main criterion for singling out a Maori presence. Still, physical appearance is a highly stereotyped criterion insofar as many Maori cannot be identified by differences in physical appearance. But, as van Meijl (2003: 63) points out, colour is for some Maori the single criterion for Maoriness, a criterion that indicates a certain socio-economic position. This is a criterion that, in tourism, as in other fields, creates a systematic pattern when compared to people with another physical appearance, and in the analysis becomes a criterion for recognition when no other Maori features are present.

Table 2 presents the frequency of the motifs found in the Maori product brochures. Surprisingly, it shows that there were no pictures of the haka. This might be explained by the fact that the most famous haka, performed by the All Blacks rugby team and usually shown in the media and adverts, originates

Table 2 Maori motifs found in Maori product brochures

\begin{tabular}{||l|c|c||}
\hline Motif & Number & \% of total \\
\hline Nature & 44 & 20.4 \\
\hline Other & 40 & 18.5 \\
\hline Tourists & 30 & 13.9 \\
\hline Carvings & 28 & 13.0 \\
\hline Traditional costume & 20 & 9.3 \\
\hline Non-traditional costume & 15 & 6.9 \\
\hline Traditional house & 11 & 5.1 \\
\hline Face tattoo & 8 & 3.7 \\
\hline Animal & 8 & 3.7 \\
\hline Wero & 3 & 1.4 \\
\hline Bonfire & 3 & 1.4 \\
\hline Traditional food & 2 & 0.9 \\
\hline Cano & 2 & 0.9 \\
\hline Poi & 1 & 0.5 \\
\hline Nose greeting (hongi) & 1 & 0.5 \\
\hline Total & 216 & 100.1 \\
\hline
\end{tabular}


in another area and in a different iwi (tribe) than those with an affiliation to this area. The relatively large 'Other' category included art, which in T4 made up many of the motifs, and was in addition a result of some of the brochures also promoting products like bungee jumping and dolphin safaris. Even if not based on what was usually regarded as Maori culture, they were sold by Maori-owned companies as well as by Pakeha. The tourist category can be understood as both tourist-as-markers - a crowd attracts an even larger crowd because it is assumed there is something to see - in MacCannell's (1976/1999: 130-131) perspective and as markers of 'tourist cultures', which have increasingly become a label of indigenous cultures (Wood, 1998). The motifs in the category 'non-traditional costume' were based on physical appearance - colour - and were of assumed Maori in modern clothing performing tasks like guiding and traditional crafts. Even if physical appearance was a criterion in use, it is important to point out that, to be singled out as a Maori motif, the motifs in the category 'non-traditional costume' needed a context in which emblematic Maori symbols where present. In some way they had to be attached to the traditional.

Following Dann's analysis, the two different sets of pictures were simply classified according to the absence or presence of people in the next step of the analysis. ${ }^{2}$ For the brochures categorised as Maori products, the presence of people was subdivided into 'tourists only', 'Maori only' - with subcategories one, two, three or more - and 'tourists and Maori together'. The category of 'Maori' was changed to 'locals' in the visitor guides. In all events, pictures with Maori motifs were also singled out as a separate category in this set of pictures. The breakdown for the Maori product brochures is provided in Table 3.

Some interesting features in Table 3 are that the category 'no people' constituted nearly half of the pictures, whereas 'tourist only' and 'Maori only' were evenly divided in the 'people' category. In Dann's material, the 'no people' category represented about one-third, whereas the 'tourist only' subcategory was nine times larger than 'locals only'. The conclusion that can be drawn is that

Table 3 People in Maori product brochure pictures

\begin{tabular}{|l|l|r|r||}
\hline Category & Subcategory & & \% of total \\
\hline No people & & 69 & 48.3 \\
\hline People & Tourists only 1 & 5 & 3.5 \\
\hline & Tourists only 2 & 12 & 8.4 \\
\hline & Tourists only 3+ & 13 & 9.1 \\
\hline & Subtotal & 30 & 21.0 \\
\hline & Maori only 1 & 15 & 10.5 \\
\hline & Maori only 2 & 8 & 5.6 \\
\hline & Maori only 3+ & 11 & 7.7 \\
\hline & Subtotal & 10 & 23.8 \\
\hline Totals & Maori and tourists & 143 & 7.0 \\
\hline
\end{tabular}


Table 3 confirms the obvious fact that the Maori themselves are regarded as objects for the tourists' gaze. The pictures in the two visitor guides were much closer to Dann's findings. A breakdown of the people versus absenceof-people dimension in this material is as shown in Table 4.

The differences between Dann's analysis and the current investigation can be explained by the respective difference between his general material distributed in the tourists' homeland and the present study, which relates to two distinct destinations and brochures found on site. Both Lake Taupo and Rotorua promote vast natural and thermal phenomena, something that can explain the relatively high percentage of the 'no people' category (36.9 vs. 24.3 in Dann's material). The lower percentage of 'tourists only' pictures (50.3 vs. 60.0) is explained partly by this variation and partly by the presence of Maori products that assumedly increase the percentage of the 'locals only' category. The latter distinction was made in particular by the Rotorua Visitor Guide, in which 20 pictures were categorised as related to Maori products. Together with the 12 Maori-related pictures in the Lake Taupo Visitor Guide, they made up 23 of the 42 pictures assigned to the 'locals only' category. The high percentage of the 'no people' category might also be partly explained by the use of the Maori as a tourist product. In all events, even if nature was a frequent motif in the Maori product brochures, it is problematic to categorise nature, even in the case of identical pictures, as Maori related in the new context of visitor guides. As well as being a marker of the indigenous-nature relation, the pictures of nature have a multivocality that also relates to frequent motifs such as sport or scenic beauty.

Tables 3 and 4 both confirm the idea that '... tourism as a meeting of peoples was somehow not to be encouraged' (Dann, 1996: 64), even less in Taupo and Rotorua than elsewhere in the world. For the visitor guides, and the Lake Taupo Visitor Guide in particular, this might be explained in part by the realisation that it was difficult to single out guides, Pakeha or Maori, in kayaks, rafts, boats, parachute jumps, etc. They were therefore categorised as tourists

Table 4 People in Visitor Guide Brochure pictures

\begin{tabular}{||l|l|r|c||}
\hline \hline Category & Subcategory & & \% of total \\
\hline No people & & 173 & 36.9 \\
\hline & Tourists only 1 & 81 & 17.3 \\
\hline & Tourists only 2 & 71 & 15.1 \\
\hline & Tourists only 3+ & 84 & 17.9 \\
\hline & Subtotal & 236 & 50.3 \\
\hline & Locals only 1 & 25 & 5.3 \\
\hline & Locals only 2 & 7 & 1.5 \\
\hline & Locals only 3+ & 10 & 2.1 \\
\hline & Subtotal & 42 & 8.9 \\
\hline Totals & Locals and tourists & 18 & 3.8 \\
\hline
\end{tabular}


insofar as the category 'locals' could only be assumed but not identified. Still, as will be discussed in the concluding part of the article, outdoor life might be an arena where indigenous people and tourists mix as contemporary in pictorial representations in tourism.

Once again following Dann, the two data sets were subsequently crosstabulated with a number of settings established by Dann in his research. The settings: beach, transport, hotel, sights, local scene, entertainment, sport, and animal scene, suggested by Dann (1996) caused some problems of categorisation. Even if both of the two destinations, Lake Rotorua and Lake Taupo, have beaches, none were featured. In the analysis, this category was made up of pools meant for bathing - no other hotel facilities were shown. Spas were categorised as entertainment, along with activities like kayaking, bungee jumping, four-wheel driving, etc. Fishing and golf were categorised as sport. In the analysis, an obviously sexist difference of categorisation was made between the poi dance and, for example, the wero. The result was that, when cultural performances were dominated by males, they were categorised as sights together with cultural exhibits, while the female poi dancers ended up in the (less heroic?) category of entertainment! If the female poi dancers had been categorised as a sight, the tendency to place Maori people as motifs to be put in this category would have been even more prominent. Alternatively, male activities could also have been classified as entertainment and consequently have increased this category. The distribution is as shown in Table 5.

Table 5 shows that most of the pictures (83.2\%) in the Maori product brochures could be categorised as sights. Only the 'no people animal' category (6), 'tourist only entertainment' (2), 'locals only local scene' (5) and 'entertainment' (3), and 'tourists and Maori entertainment' (2) were represented by more than one picture. A comparison of each category of people with the overall marginal percentages reveals where they were overrepresented (Dann, 1996).

It is interesting to note how this zoning in the Maori product brochures can easily be contested. No pictures were categorised according to sport. Anyone who has ever been to a New Zealand gym or has the slightest knowledge of Kiwi anglers or the national obsession with rugby will know that Maori are not absent from sport or from the beaches in daily life. Neither does one need much historical knowledge of Maori involvement in sports to contest this image. Maoris became a part of New Zealand sports early on, and many Maoris playing for the world-famous All Blacks have acquired the status of national heroes. As King (2003: 387) puts it: 'For New Zealand men as whole, Maori and Pakeha, playing and following rugby was the great common denominator they could share as players and supporters and as a sure-fire topic for socially bonding conversation'. Rather, the absence of Maori in the 'sport' category points to the indigenous as a distinct category in modern tourism. This is revealed by the analysis of the visitor guides, in which the Maori cluster in certain categories (Table 6).

When the distribution of location by people was examined in visitor guides, a much more varied picture than in the product brochures was revealed. In spite of this contrast, the same pattern as in the Maori product brochures was repeated when pictures with Maori motifs were taken into consideration. The 
Table 5 Distribution of location by people in Maori product brochures

\begin{tabular}{|c|c|c|c|c|c|c|c|c|c|}
\hline \multirow[b]{2}{*}{ People category } & \multicolumn{8}{|c|}{ Location } & \multirow[b]{2}{*}{ Total \% } \\
\hline & Beach & Transport & Hotel & Sights & Local scene & Entertainment & Sport & Animal scene & \\
\hline No people $(n=69)$ & - & 1.4 & - & 89.9 & - & - & - & 8.7 & 100.0 \\
\hline $\mathrm{T} 1$ & - & - & - & 60.0 & - & 20.0 & - & 20.0 & 100.0 \\
\hline $\mathrm{T} 2$ & - & - & 8.3 & 83.3 & - & 8.3 & - & - & 99.9 \\
\hline T3+ & 7.7 & - & - & 84.6 & 7.7 & - & - & - & 100.0 \\
\hline T only $(n=30)$ & 3.3 & - & 3.3 & 80.0 & 3.3 & 6.7 & - & 3.3 & 99.9 \\
\hline M1 & - & - & - & 73.3 & 26.7 & - & - & - & 100.0 \\
\hline M2 & - & - & - & 87.5 & 12.5 & - & - & - & 100.0 \\
\hline M3+ & - & - & - & 72.7 & - & 27.3 & - & - & 100.0 \\
\hline M only $(n=34)$ & - & - & - & 76.5 & 14.7 & 8.8 & - & - & 100.0 \\
\hline Tourists and Maori $(n=10)$ & - & 10.0 & - & 70.0 & - & 20.0 & - & - & 100.0 \\
\hline All $(n=143)$ & 0.7 & 1.4 & 0.7 & 83.2 & 4.2 & 4.9 & - & 4.9 & 100.0 \\
\hline
\end{tabular}

T, tourists; M, Maori 
Table 6 Distribution of people by location in Maori product brochures

\begin{tabular}{|c|c|c|c|c|c|c|c|c|c|}
\hline \multirow[b]{2}{*}{ People category } & \multicolumn{8}{|c|}{ Location } & \multirow[b]{2}{*}{ Total \% } \\
\hline & Beach & Transport & Hotel & Sights & Local scene & Entertainment & Sport & Animal scene & \\
\hline No people & - & 50.0 & - & 52.1 & - & - & - & 85.7 & 48.3 \\
\hline Tourists & 100.0 & - & 100.0 & 20.2 & 16.7 & 28.6 & - & 14.3 & 21.0 \\
\hline Maori & - & - & - & 21.8 & 83.3 & 42.8 & - & - & 23.8 \\
\hline Tourists and Maori & - & 50.0 & - & 5.9 & - & 28.6 & - & - & 7.0 \\
\hline NS & 1 & 2 & 1 & 119 & 6 & 7 & 0 & 7 & 143 \\
\hline Total \% & 100.0 & 100.0 & 100.0 & 100.0 & 100.0 & 100.0 & & 100.0 & 100.1 \\
\hline
\end{tabular}


Maori constituted a sizeable percentage of the 'locals only' and the 'tourists and locals' categories in the sights location. The same was the case for 'tourists and locals' in entertainment. Of all locals, $52.1 \%$ were categorised as Maori, with sights making up $42.9 \%$ of this category. 'No people' and 'tourists only' had $1.7 \%$ each and 'tourists and locals' had $16.7 \%$. Of all pictures, only $6.8 \%$ were related to Maori motifs, something that gives further weight to the claim that the indigenous occupy only certain small zones in modern tourism. As shown in Tables 7 and 8, these zones were within the frameworks of sights and entertainment. This means that, in further analysis, attention should be paid to the locations where Maori were not present, and that it becomes necessary to understand what makes the locations of sights and entertainment different from the others (Figures 1-3).

Dann (1996: 78) points out in his analysis that, according to the representations in tourist brochures, $90 \%$ of the tourist trade belonged to the operators. If tourists wished to pursue the indigenous, this quest could be conducted by the remaining 10\%. My analysis reveals that a different pattern obtains when the locals themselves constitute an attraction. In Maori product brochures (Table 3), the category 'Maori only' comprises 23.8\% of the pictures, whereas 'tourists only' account for $21.0 \%$ and $7.0 \%$ of the pictures for 'Maoris and tourists together'. Even in these two areas and with a considerable Maori population, the visitor guides (Table 4) are much more in sync with Dann's (1996: 63) general findings, with, respectively, $36.9 \%$ and $24.3 \%$ 'no people', $50.3 \%$ and $60.1 \%$ 'tourists only', $8.9 \%$ and $6.7 \%$ 'locals only', and $3.8 \%$ and $8.9 \%$ in the 'locals and tourists' category.

This difference between Dann's general perspective, the visitor guides, and the Maori brochures persists when zoning is considered. In the Maori product brochures, all categories cluster at the 'sight' category, with only a few elements of 'local scene' and 'entertainment' when Maori are present (Table 5). Table 6, which shows distribution of people by location in Maori product brochures, reveals that Maori, as a tourist attraction, are found predominantly at sights, but may also be encountered at a local scene or on stage as entertainment. Furthermore, the Maori spirits can be experienced by the tourist at various sights. It is also revealed that Maori are not found at beaches, sport events, hotels, or when animals are present, although the odd Maori can be seen in association with transport. When the visitor guides are considered (Tables 7 and 8) according to location, once again they correspond much more to the findings of Dann's (1996: 65-66) general account. Locals are present at many more locations, but still, when Maori images are considered, this part of the local population, except for one picture, belongs to the locations of sights and entertainment.

This article suggests that these two locations provide temporal and spatial arrangements that uphold the differences between the modern and the image of the indigenous Maori. In these zones the Maori can be encountered as traditional and timeless and, simultaneously, as they are in everyday life. They can be seen in other locations as a part of a modernity in which they are of no interest for the tourists' gaze. To be interesting for the tourist, the Maori have to be positioned differently within time and space than the tourists who gaze upon them. They have to be relegated to "a "point in time" which was 
Table 7 Distribution of location by people in Visitor Guide pictures

\begin{tabular}{|c|c|c|c|c|c|c|c|c|c|}
\hline \multirow[b]{2}{*}{ People category } & \multicolumn{8}{|c|}{ Location } & \multirow[b]{2}{*}{ Total \% } \\
\hline & Beach & Transport & Hotel & Sights & Local scene & Entertainment & Sport & Animal scene & \\
\hline No people $(n=173)$ & 1.2 & 13.9 & 52.0 & $27.7(1.7)$ & - & 0.9 & 1.2 & 3.5 & 100.0 \\
\hline $\mathrm{T} 1$ & 1.2 & 2.5 & 8.6 & $16.0(1.2)$ & - & 33.3 & 38.3 & - & 100.0 \\
\hline $\mathrm{T} 2$ & 4.2 & 5.6 & 12.7 & $28.2(1.4)$ & - & 28.2 & 21.1 & - & 99.9 \\
\hline T3+ & 6.0 & 8.3 & 14.3 & $15.5(2.4)$ & - & 53.6 & 2.4 & - & 100.0 \\
\hline T only $(n=236)$ & 3.8 & 5.5 & 11.9 & $19.5(1.7)$ & - & 39.0 & 20.3 & - & 99.9 \\
\hline M1 & - & $4.0(4.0)$ & 8.0 & $48.0(44.0)$ & 32.0 & $8.0(4.0)$ & - & - & 100.0 \\
\hline M2 & - & - & - & $57.1(57.1)$ & - & $28.6(14.3)$ & - & 14.3 & 100.0 \\
\hline M3+ & - & - & - & $50.0(30.6)$ & 30.0 & $10.0(10.0)$ & - & 10.0 & 100.0 \\
\hline M only $(n=42)$ & - & $2.4(2.4)$ & 4.8 & $50.0(42.9)$ & 26.2 & $11.9(7.1)$ & - & 4.8 & 100.0 \\
\hline Tourists and Maori $(n=18)$ & - & 11.1 & 22.2 & $27.8(16.7)$ & - & 22.2 & 5.6 & 11.1 & 100.0 \\
\hline All $(n=469)$ & 2.3 & $8.5(0.2)$ & 26.4 & $25.6(6.0)$ & 2.3 & $21.7(0.6)$ & 10.9 & 2.1 & 100.0 \\
\hline
\end{tabular}

Pictures with Maori motives parented $(n=33)$. T, tourists; M, Maori 
Table 8 Distribution of people by location in Visitor Guides

\begin{tabular}{|c|c|c|c|c|c|c|c|c|c|}
\hline \multirow[b]{2}{*}{ People category } & \multicolumn{8}{|c|}{ Location } & \multirow[b]{2}{*}{ Total \% } \\
\hline & Beach & Transport & Hotel & Sights & Local scene & Entertainment & Sport & Animal Scene & \\
\hline No people & 18.2 & 60.0 & 72.6 & $40.0(2.5)$ & - & 1.0 & 3.9 & 60.0 & 36.9 \\
\hline Tourists & 81.8 & 32.5 & 22.6 & $38.3(3.3)$ & - & 90.2 & 94.1 & - & 50.3 \\
\hline Locals & - & $2.5(2.5)$ & 1.6 & $17.5(15.6)$ & 100.0 & 4.9 & - & 20.0 & 9.0 \\
\hline Tourists and locals & - & 5.0 & 3.2 & $4.2(2.5)$ & - & $3.9(2.9)$ & 2.0 & 20.0 & 3.8 \\
\hline NS & 11 & $40(1)$ & 124 & $120(28)$ & 11 & $102(3)$ & 51 & 10 & $469(32)$ \\
\hline Total \% & 100.0 & $100.0(2.5)$ & 100.0 & $100.0(23.3)$ & 100.0 & $100.0(2.9)$ & 100.0 & 100.0 & $100.0(6.8)$ \\
\hline
\end{tabular}

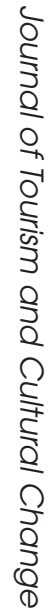



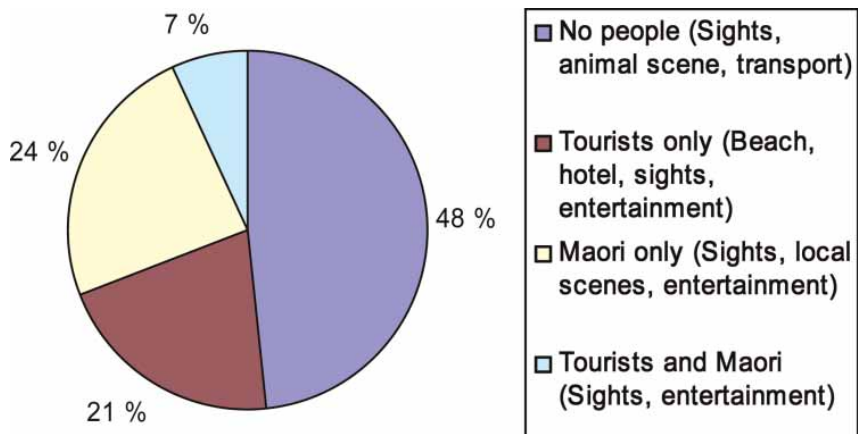

Figure 1. The zoning of peoples in Maori product brochures.



\begin{tabular}{l}
\hline No people (Transport, \\
hotel, sights, animal \\
scenes) \\
$\square$ Tourists only (Beach, \\
sights, entertainment, \\
sport) \\
$\square$ Locals only (Sights, \\
local scenes, \\
entertainment) \\
$\square$ Tourists and locals \\
(Hotel, sights, \\
entertainment)
\end{tabular}

Figure 2. The zoning of peoples in Visitor Guides.

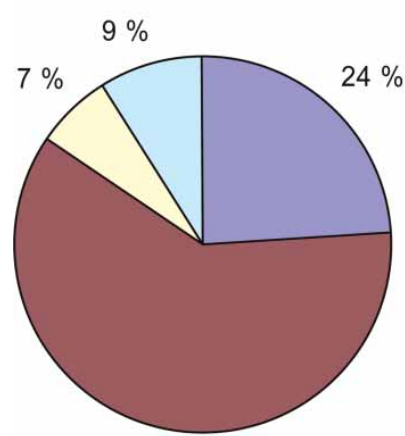

$60 \%$



Figure 3. The zoning of peoples (Dann, 1996: 67). 


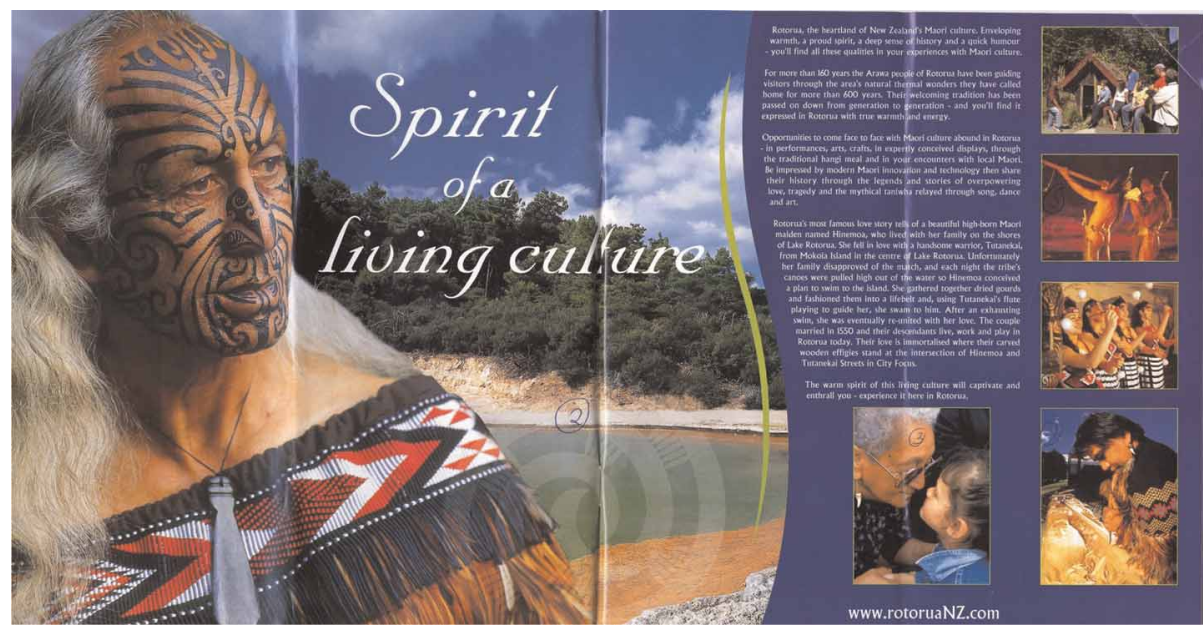

Picture 2. Rotorua Visitor Guide.

"prehistoric". The point at which society moves from prehistoric to historic is also the point at which tradition breaks with modernism' (Smith, 1999: 55). Without the spatial and temporal arrangements that situate the Maori as 'prehistoric' and timeless, they become contemporaries and have less possibility of attracting the tourists' attention (Picture 2).

Only in two, or maybe three, categories does it seem that the division between the traditional Maori and the modern tourists is bridged. In an educational setting, guides in modern clothing are found together with tourists, and in several pictures in the 'Maori alone' category obviously contemporary Maori are doing handicraft. More speculative is that there seems to be no need for Maori tourist companies to relate to their heritage when promoting products connected to outdoor life. Nevertheless, on these occasions it is impossible for an outsider to distinguish between producers and tourists. Nor do these three aberrations overshadow the overall picture of the Maori as traditional.

\section{Conclusion}

A question might be raised about the use of scholarly 'readings' of exotic images. They often neglect the view of the people - tourists as well as locals under consideration and all too often reveal an only general Western perspective on the Other. By emphasising such a general perspective, these readings neglect the situatedness of the scholar herself. In this manner, the analysis often becomes a reification of what Friedman (1999: 315) calls 'a larger inversion of Western cosmology'.

Nevertheless, by applying the method of controlled comparison, in this case between brochures promoting tourism in general, brochures promoting two particular destinations, and brochures promoting Maori cultural products, such a situated reading can be transcended to a certain degree (Bruner, 2001; Eggan, 1954). The arbitrary way of establishing categories and the stereotyped 
selection of ethnic markers is challenged. In this analysis the systematic difference between female activities placed in the 'entertainment' setting and male activities that are relegated to the category of 'sight' is probably a consequence of the researcher's prejudices. The same may apply to the categorisation of guides and tourists in kayaks, rafts, boats, and parachute jumps. People portrayed in these pictures were categorised as tourists as long as 'locals only' could be assumed but not identified. Many of these activities are sold by Maori-led companies, Maori people engage in these activities, and these motifs could just as well be categorised as an example of a modernity in which Maori and Other interact in co-presence.

In spite of the researcher being situated, the controlled comparison reveals a certain structural frame of the way the Maori are represented in tourism. The overwhelming majority of what reasonably can be identified as representing the 'Maori only' category are relegated to two distinct settings: entertainment and sights. Without the researcher's gendered bias, this would be gathered into a single setting. In both settings, the Maori appear as a timeless traditional people. In addition, the systematic disappearance of the 'tourists only' category from Dann's material, via the brochures promoting the destination and as well as those that emphasise the Maori, points to a particular position in touristic representation. This is a reproduction of an image common in Western thought. Regarded as auto-ethnography, the bulk of these pictorial representations can be understood as 'self-Orientalism'.

If at least a part of modern tourism is a search for something that people assume is different and better than their everyday life - a paradise - it seems that Maori tourist entrepreneurs find only certain realms suitable for the advertising of their own products. The past can be seen in the pictures and at sites. Except for these two realms, the Maori, according to the tourist brochures, have no place in the modernity where tourists are usually situated during their holidays in the Lake Taupo or Rotorua areas. Nevertheless, without such temporal and spatial arrangements, the Maori would not appear as tourist attractions because they then become a part of the less-sensational contemporary everyday life. Hence Pratt's concept of contact zone necessitates a more thorough understanding.

Assuming that the producers of these brochures are actors sometimes 'within radically asymmetrical relations of power' (Pratt, 1992: 7) that handle a business, it is not surprising that they relate to images marketed by a global industry. This is done by relating to a distinct tradition of representing the Maori, and it is therefore necessary to situate an analysis in the New Zealand context. Claiming a general image of indigenous peoples might well pay attention to certain ideas in Western thought but miss the different histories and modernities of all the peoples lumped together into the broad category of indigenousness (Friedman, 1999; Hannerz, 1996). In addition, a general perspective is in danger of overlooking those rare representations that bring indigenous people into co-presence with modern tourists. In the case of the Maori, this co-presence is highly visible in the 'tourists and Maori' category, where Maori exhibit their culture in an educational setting. Perhaps more striking are the images in which modern clothing and traditional handicraft are represented in a way that undoes the distinction between tradition and modernity 




Picture 3. Tamaki Maori Village.

but represents a Maori modernity. A third such example might be the outdoor activities in which dominance of the exotic in the tourism discourse in general does not seem to matter. All these glimpses of a different Maori reality point to both the producers' possibility of creating a more nuanced image as well the necessity of analysing such a representation in a distinct social context. But still, the overwhelming image presented of the Maori as tourist attractions in these brochures is that of a traditional people. There are glimpses of different images, but it is still difficult to imagine that tourist brochures will include 'images of Maori sitting at their word processors!' (Picture 3).

This is not to say that tourists necessarily do not regard the Maori as contemporary. As already said, image making in tourism is a process in which the brochures analysed in this article represent only a certain stage (Dann, 1996, 2001: 5; Gunn, 1997: 29; Wang, 2000: 135-136). Tourists probably know that the Maori are modern citizens in a nation-state, and, by actually encountering Maori attractions, tourists might come to different understandings of Maori culture (Taylor, 2001). As in the case of the Maori producers, it must be assumed that the tourists understand the fact that the Maori are at the same time modern people and traditional is what attracts the tourists' gaze. Nevertheless, it is mainly the Maori as a rather stereotype traditional people that the autoethnographic brochures provide, and this is what Lee (2006: 469) calls the 'bugbear of authenticity', connected to a status as indigenous. To gain the public receptivity connected to the indigenous world, the indigenous have to deliver authenticity, whatever that means.

\section{Correspondence}

Any correspondence should be directed to Kjell Olsen, Finnmark University College, Follumsvei, 9509 Alta, Norway (kjell@hifm.no). 


\section{Notes}

1. The White and Pink Terraces were destroyed by an earthquake in 1886.

2. The tourist category can be described as adult Caucasians. Anyhow, a registration of gender, age, and the different constellation on the pictures was not made.

\section{References}

Asplet, M. and Cooper, M. (2000) Cultural designs in New Zealand souvenir clothing: The question of authenticity. Tourism Management 21, 307-312.

Barnett, S. (1997) Maori Tourism. Tourism Management 18, 471-473.

Bishop, R. and Glynn, T. (1999) Culture Counts. Changing Power Relations in Education. Palmerston North: Dunmore Press.

Bruner, E.M. (1995) The etnographer/tourist in Indonesia. In M.-F. Lanfant, J.B. Allcock and E.M. Bruner (eds) International Tourism. Identity and Change (pp. 224-241). London: Sage.

Bruner, E.M. (2001) The Maasai and the Lion King: Authenticity, nationalism, and globalization in African tourism. American Ethnologist 28, 881-908.

Buzinde, C.N., Santos, C.A. and Smith, S.L.J. (2006) Ethnic representations: Destination imagery. Annals of Tourism Research 33, 707-728.

Dann, G.M.S. (1996) The people of tourist brochures. In T. Selwyn (ed.) The Tourist Image. Myths and Myth Making in Tourism (pp. 61-81). Chichester: Wiley.

Dann, G.M.S. (1999) Writing out the tourist in space and time. Annals of Tourism Research 26, 159-187.

Dann, G.M.S. (2001) The self-admitted use of cliché in the language of tourism. Tourism, Culture \& Communication 3, 1-14.

Echtner, C. (2000) The context of third world tourism marketing. A 4A approach. International Journal of Tourism Research 30, 660-682.

Eggan, F. (1954) Social anthropology and the method of controlled comparison. American Anthropologist 56, 743-763.

Fabian, J. (1991) Time and the Work of Anthropology. Critical Essays 1971-1991. Chur: Harwood Academic Publishers.

Friedman, J. (1999) Indigenous struggles and the discreet charm of the bourgeoisie. Journal of World-Systems Research 5, 315-329, http://csf.colorado.edu/wsystems/ jwsr.html.

Gingging, F.A.M. (2007) 'I lost my head in Borneo': Tourism and the refashioning of the headhunting narrative in Sabah, Malaysia. Cultural Analysis 6, 1-29.

Goldsmith, M. (2003) 'Our Place' in New Zealand culture: How the museum of New Zealand constructs biculturalism. Ethnologies comparées 6, 1-14, http://alor.univmontp3.fr/cerce/revue.htm.

Gunn, C.A. (1997) Vacationscape. Developing Tourist Areas (3rd edn). Washington, DC: Taylor \& rancis.

Hannerz, U. (1996) Transnational Connections: Culture, People, Places. London: Routledge. Hulme, K. (1984/2001) The Bone People. London: Picador.

King, M. (2003) The Penguin History of New Zealand. Auckland: Penguin.

Lee, R.B. (2006) Twenty-first century indigenism. Anthropological Theory 6, 455-479.

MacCannell, D. (1976/1999) The Tourist. A New Theory of the Leisure Class. Berkeley: University of California Press.

McCarthy, C. (2007) Exhibiting Mâori. A History of Colonial Cultures of Display. Oxford: Berg.

McIntosh, A.J., Zygadlo, F.K. and Matunga, H. (2004) Rethinking Maori tourism. Asia Pacific Journal of Tourism Research 9, 331-351.

Neich, R. (1983) The veil of orthodoxy: Rotorua Ngati Tarawhai Woodcarving in a changing context. In S.M. Mead and B. Kernot (eds) Art and Artists of Oceania (pp. 245-265). Palmerston North: Dunmore Press.

Pratt, M.L. (1992) Imperial Eyes. Travel Writing and Transculturation.. London: Routledge.

Robinson, M. (2005) The trans-textured tourist: Literature as knowledge in the making of tourists. Tourism Recreation Research 30, 73-81. 
Ryan, C. (1997) Maori and tourism: A relationship of history, constitutions and rites. Journal of Sustainable Tourism 5, 257-278.

Ryan, C. and Crotts, J. (1997) Carving and tourism: A Maori perspective. Annals of Tourism Research 24, 898-918.

Ryan, T. (2002) 'Le Président des Terres Australes': Charles de Brosses and the French enlightenment beginnings of oceanic anthropology. The Journal of Pacific History 37, 157-186.

Said, E.W. (1978) Orientalism. Western Conceptions of the Orient. New York: Panthenon.

Smith, G.H. (1993) The commodification of knowledge and culture. Overview: A newspaper about justice and development (Vol. 45, pp. 6-9). Wellington: CORSO.

Smith, L.T. (1999) Decolonizing Methodologies. Research and Indigenous Peoples. London: Zed Books.

Sturma, M. (1999) Packaging Polynesia's image. Annals of Tourism Research 26, 712-715.

Tamaki Maori Village n.d

Taylor, J.P. (2001) Authenticity and sincerity in tourism. Annals of Tourism Research 28, $7-26$.

Urry, J. (1990) The Tourist Gaze. Leisure and Travel in Contemporary Societies. London: Sage.

van Meijl, T. (2003) Maori tribal organisations in New Zealand history: From neglect to recognition, and the implications for the assimilation policy. Ethnologies comparées 6, 1-30, http://alor.univ-montp3.fr/cerce/revue.htm.

Wang, N. (2000) Tourism and Modernity. Amsterdam: Pergamon.

Webster, S. (1998) Patrons of Maori Culture. Power, Theory and Ideology in the Maori Renaissance. Dunedin: University of Otago Press.

Wood, R.E. (1998) Touristic ethnicity: a brief itinerary. Ethnic and Racial Studies 21, 218-241.

Young, B. (1989) New Zealand - Maori tourism on the launch pad. Tourism Management 10, 153-156.

On WWW at http://www.newzealand.com/travel (Accessed 2 January 2007)

On WWW at http://www.stats.govt.nz/census/2006-census-data/quickstats-aboutnzs-pop-and-dwellings/quickstats-about-nzs-pop-and-dwellings.htm?page $=$ para005 Master (Accessed 2 January 2007) 